\title{
KONSEP PENDIDIKAN ANAK MENURUT IBNU KHALDUN (Studi Atas Kitab Muqaddimah)
}

\author{
Ahmad Falah
}

Jurusan Tarbiyah STAIN Kudus

\begin{abstract}
The concept of a child's education, according to Ibn Khaldun in his book Prolegomena can be grouped into several important part of the concept and his thinking, ie on the basics of education, the division of sciences, there is science and science naqliyah aqliyah, the basic principles of Islamic education, educational purposes, methods, materials, nature educators and students as well as a discussion of the teaching of the Koran and Arabic for the countries of the Arab world and Africa The purpose of education according to Ibn Khaldun is the religious and moral education, Islamic education and the world's attention to the interests of religion, Islamic education prioritize aspects of expediency, Islamic education to educate children to study not merely for science alone but for the provisions that can be applied to the next life, Islamic education is concerned with vocational education (vocational), art, carpentry in order to find work and good luck.

Curriculum (material) according to Ibn Khaldun is material to the base rate includes: Koran, joints religion, reading, writing, arithmetic, the basics of the Arabic language, moral education, stories, syi'ir and ktrampilan, and material to a high level (higher education) include religion and literatures, and sciences that support the life eg foreign language.
\end{abstract}

Keywords: Ibn Khaldun, the education of children

\section{PENDAHULUAN}

\section{A.I. Latar Belakang Masalah}

Pendidikan merupakan salah satu penopang sebuah negara, ia memiliki peranan penting dalam upaya pencapaian kemajuan 83 
bangsa. Pendidikan merupakan salah satu fenomena sosial yang sangat mempengaruhi pertumbuhan dan perkembangan individu dan masyarakat yang melibatkan orang tua, pendidikan dan lingkungan.

Sebagian dari masyarakat adalah anak sebagai individu yang pada prinsipnya memiliki akal yang sehat yang dapat dan harus dimanfaatkan untuk mencari ilmu pengetahuan. Potensi tersebut memberi kemungkinan kepada anak untuk mengembangkan kepribadiannya. Pengembangan akal pikiran yang sehat dilatarbelakangi oleh kesadaran berfikir yang dimiliki oleh anak. (Abdullah Nashih Ulwan, 1990 : VII)

Dalam perkembangan kepribadian, akal fikiran dan potensi anak yang melalui fase-fase perkembangan tertentu, anak memerlukan bimbingan, pengajaran, pengendalian dan kontrol dari orang tua dan pendidik. Anak yang merupakan dasar awal dari pembentukan menjadi dewasaharusdiperhatikan dengan sungguh perkembangannya oleh orang tua dan pendidik. Hal ini dengan tujuan mempersiapkan perkembangan anak agar mampu berperan serta secara berkesinambungan dalam pembangunan manusia yang berkembang terus dan mampu beramal kebajikan dalam arti berakhlak mulia selama dalam upaya mencari kebahagiaan di dunia dan akhiratnya. (Ali Al-Jumbulati, 1994 : 4)

Anak tidak dapat tumbuh dan berkembang serta menerima ilmu pengetahuan begitu saja, tetapi harus dengan pengajaran dan bimbingan dari orang tua dan pendidik. Orang tua dan pendidiklah dan didukung oleh lingkungan baik yang berperan dalam mengembangkan bakat dan minat anak, karena factor yang dari dalam yaitu faktor keturunan tidak banyak pengaruhnya pada diri anak. Hal ini dapat dikatakan bahwa anak secara fitri (alami) bersih dari warna tertentu dan mirip dengan teori tabula atau lembaran putih yang dikemukakan oleh tokoh pendidikan Barat yaitu Jhon Lock. Sedangkan proses belajar serta mendapatkan ilmu pengetahuan sama dengan proses menulis dan membuat garis di atas lembaran putih tersebut. (Fathiyah Hasan Sulaiman, 1991 : 92)

Teori John Locke dan juga J.J. Rosseau tentang anak-anak yang baru lahir dalam keadaan bersih. John memandang anak yang lahir bagaikan kertas putih. Aliran ini punya pengikut yang besar di Amerika Serikat serta membuka jalan bagi tumbuhnya aliran-aliran yang besar pengaruhnya dalam dunia psikologi yanitu Behaviorisme yang terus berkembang sampai sekarang. Ternyata Ibnu Khaldun terlahir 27 Mei $1331 \mathrm{M}$ dari keluarga politisi, intelektual dan aristocrat di Moorsih, telah lama mengedepankan ide tersebut meskipun dalam versi yang berbeda. 
Konsep tersebut sejalan dengan hadits Nabi Muhammad Saw. yaitu "tidak ada bayi yang dilahirkan kecuali dalam keadaan suci (fitrah), kedua orang tuanyalah yang menjadikannya Yahudi, Nasrani atau Majusi" Muslim, tt : 458)

Dari sinilah dapat ditarik pengertian bahwa peranan dan tanggung jawab orang tua selaku pendidik utama dan pertama dan pendidik dalam arti guru sangat besar dalam mengantarkan anak ke jenjang pendidikan yang lebih baik dan membentuk anak agar tumbuh dan berkembang dengan baik dan sempurna hingga dewasa.

Perkembangan dunia pendidikan tentunya tidak akan terlepas dari sumbangsih para ilmuwan yang mencurahkan segala perhatiannya pada dunia pendidikan ini. Begitu pun yang dilakukan oleh para ulama sebagai yang merasa berkewajiban untuk menyebarluaskan ilmu. Salah satu ulama besar, filosof, psikolog dan sosiolog sekaligus intelektual muslim yakni Ibnu Khaldun. Maka dari sinilah dirasa perlu menampilkan konsep dan pemikiran beliau tentang pendidikan anak yang menyoroti mengenai peran, tugas dan tanggung jawab pendidik terhadap anak dalam proses belajar mengajar atau interaksi edukatif. Beliau mengatakan "tidak cukup seorang pendidik hanya membekali anak dengan ilmu pengetahuan saja agar mereka menjadi orang yang berilmu pengetahuan menambah kemampuannya dalam belajar Akan tetapi juga pendidik wajib memperbaiki metoda dalam penyajian ilmu kepada anak didiknya; dan hal itu tidak akan sempurna kecuali dengan lebih dahulu mempelajari hidup kwajiban anak dan mengetahui tingkat-tingkat kematangannya serta bakat-bakat ilmiahnya, sehingga ia mampu menerapkan sesuai dengan tingkat pikiran mereka". (Ali Al-Jumbulati : 195-196)

Dengan adanya hal seperti itu merupakan sesuatu yang melatarbelakangi mengadakan penelitian ini, disamping karena adanya keinginan mengkaji hasil konsep dan pemikiran salah seorang tokoh terdahulu yang sangat terkemuka dengan kitabnya yang bejudul Muqaddimah. Mengingat sebagian para pelajar dan akademika yang lebih condong kepada karya pemikir Barat dan lebih tertarik dengan pendidikan sekuler, sehingga mereka sering terjebak dan termakan oleh teori dan praktek pendidikan Barat, namun hal ini bukanlah berarti harus dihindari atau ditolak, tetapi hendaknya ilmu pengetahuan itu diambil dan dipelajari dengan membuang yang tidak baik dan menambah yang kurang selama hal itu bermanfaat dan tak lupa selalu berpegang kepada al-Qur'an, as-Sunnah dan ijtihad yang istilah sekarang dengan lewat 
islamisasi ilmu pengetahuan.

Sosok figur Ibnu Khaldun sebagai sarjana dan ulama besar, kebanggaan umat Islam dan pencipta ilmu sosial benar-benar merupakan pujaan dan bintang kejora. (Nashrudddin Thoha, 1979 : 58) Ibnu Khaldun sebagai ulama dan sarjana besar menurut etimologi dan semantiknya, keahliannya dan ilmunya tidak tanggung-tanggung di seluruh bidang ilmu-ilmu naqliyah yang mencakup ilmu-ilmu agama dan ilmu alat dan ilmu-ilmu aqliyah yang meliputi ilmu-ilmu umum.

Beliautidakhanya seorangsosiolog, beliaujuga seorangsejarawan dan tokoh pemikir pendidikan, hal ini ditinjau pada pendidikan anakanak. Pengalamannya sebagai mahaguru di Universitas al-Azhar yang dibangun oleh khalifah al-Muiz dari dinasti Fatimiyah yang ada di Kairo Mesir dan guru besar di universitas Sragtmus. Selama 20 tahun lebih beliau memberikan kuliah dan tentunya beliau mempunyai wawasan yang luas, pemikiran yang mendalam sehingga patut dikaji dan diteliti.

Umat Islam yang pada umumnya menyakini akan kealiman dan kemasyhuran Ibnu Khaldun yang mana N.J. Dawood menyebutnya sebagai negarawan, ahli hokum, sejarawan dan sarjana, (Ahmad Syafi'i, 1996 : 11) Ma'arif maka ironisnya sekali apabila tidak mengenal terhadap mutiara konsep dan pemikiran beliau dengan karya sosial historisnya Muqaddimah yang diakui dunia.

Konsep dan pemikiran Ibnu Kaldun khususnya tentang pendidikan anak masih aktual dan pantas untuk digali serta ditampilkan, seperti orientasi pendekatan ilmu kepada anak-anak melalui contoh kehidupan, pendidik harus membawakan teladan utama contoh yang baik bagi anak dan sebagainya. Konsep dan pemikiran Ibnu Khaldun tidak dapat dipisahkan dari akar pemikiran Islamnya. Disinilah letak alasan Iqbal mengatakan bahwa seluruh semangat Muqaddimah yang merupakan manifestasi pemikiran Ibnu Khaldun,diilhami pengarangnya dari al-Qur'an sebagai sumber utama dan pertama dari ajaran Islam. Dengan demikian konsep Ibnu Khaldun dapat dibaca melalui setting sosial yang mengitarinya yang diungkapkan baik secara lisan maupun tulisan sebagai sebuah kecenderungan.

\section{Perumusan Masalah}

Dari uraian di atas, penelitian dilakukan karena adanya suatu masalah yang membutuhkan pembahasan atau penyeleseian. Masalah dalam penelitian berarti juga fokus yang menjadi pusat pembahasan. 
Secara umum masalah adalah suatu keadaan yang bersumber dari dua faktor atau lebih yang menghasilkan situasi yang membingungkan. (Lexy. J. Moleong, 1993 : 62)

Dalam penelitian ini masalah ini terfokus pada :

1. Bagaimana konsep pendidikan anak menurut Ibnu Khaldun dalam kitab Muqaddimah.

2. Bagaimana relevansi konsep pendidikan anak Ibnu Khaldun dalam kitab Muqaddimah dengan pendidikan anak dewasa ini

\section{Tujuan Penelitian}

Dari masalah permasalahan yang dikemukakan di atas, maka tujuan penelitian ini adalah untuk mengetahui konsep Ibnu Khaldun tentang pendidikan anak. Adapun secara khusus, tujuan penelitian adalah :

a. Mendeskripsikan konsep pendidikan anak menurut Ibnu Khaldun dalam kitab Muqaddimah.

b. Mencari relevansi konsep pendidikan anak Ibnu Khaldun dalam kitab Muqaddimah dengan konsep pendidikan anak dewasa ini

\section{Kegunaan Penelitian}

a. Dapat memberikan kontribusi positif bagi pendidikan anak, khususnya sewaktu berlangsungnya proses belajar dan interaksi edukatif.

b. Untuk memberikan kontribusi ilmiah terhadap dunia pendidikan Islam, khususnya dalam memperkaya khazanah konsep pendidikan anak, yaitu mengambil pemikiran-pemikiran positif dari konsep yang diajukan Ibnu Khaldun untuk diterapkan dalam pelaksanaan pendidikan Islam.

c. Memberi nuansa atas paradigma pendidikan Islam yang lebih menyentuh realitas budaya modern dan proporsional terutama dalam wilayah konsep filosofis-teoritis.

\section{Telaah Pustaka}

Saat penulis mengadakan pelacakan literatur yang membahas konsep pendidikan Ibnu Khaldun, ternyata ada beberapa literatur konsep Ibnu Khadun baik yang bersifat normatif maupun empiris, namun literatur atau karya yang mengkaji tentang konsep pendidikan Islam menurut Ibnu Khaldun masih sedikit, yaitu karya-karya yang 87 
berupa buku atau tulisan disertasi dan tesis.

Pembahasan tentang konsep dan pemikiran Ibnu Khaldun dalam bidang pendidikan secara parsial telah banyak dilakukan dalam kajiankajian oleh peneliti-peneliti terdahulu. Hal ini terjadi karena pendidikan sebagai faktor penting perubahan suatu zaman (agent of change )

Sekedar contoh untuk karya-karya terdahulu yang dimaksud antara lain adalah Ibnu Khaldun dalam pandangan penulis Baratdan Timur oleh A.Syafi'i Ma'arif (tahun 1996), yang menerangkan tentang penilaian dari pemikir-pemikir Barat yang telah mengakui kemasyhuran beliau dan mengakui keilmuan beliau, dan konsep-konsep beliau digunakan di dunia Barat. Begitu juga pemikir-pemikir dari dunia Timur telah banyak menggunakan keilmuan dan konsep beliau dan dijadikan dasar dan pijakan konsep tokoh-tokoh sesudahnya. Tokoh-tokoh Pendidikan Islam Masa Jaya Imam al-Ghazali dan Ibnu Khaldun oleh Nasruddin Thoha (tahun 1979), Buku ini menerangkan tentang tokoh-tokoh pendidikan Islam yang sekurun dalam arti hidup bersama al-Ghazali dan Ibnu Khaldun, seperti pemikiran pendidikan Islam al-Qabisi, dan pemikiran pendidikan Islam Ibnu Sina dan lain-lain Konsep Pedagogik Ibnu Khaldun oleh Warul Walidin (disertasi tahun 1996), tulisan ini membahas tentang konsep belajar mengajar secara umum, ketika manusia mau menuntut ilmu dan belajar, juga bagaimana cara seorang guru mengajarkan ilmu yang baik kepada anak didik. Dalam tulisan disertasi di atas, penulis menitik beratkan pada pendidikan anak didik dewasa yang ingin belajar ilmu-ilmu agama dan ilmu-ilmu umum atau ilmu-ilmu naqliyah dan ilmu-ilmu aqliyah. Ibnu Khaldun dan Progresivisme oleh Siswadi (tesis tahun 2002), tulisan ini membahas tentang adanya tawaran untuk mencari titik temu dan harmonisasi atau sinkronisasi pemikiran Ibnu Khaldun dengan konsep belajar progresisvisme, apakah ada relevansi dan hubungannya atau tidak.

Secara kuantitatif, buku dan tulisan yang membahas Ibnu Khaldun yang ditinjau dari konsep pendidikannya cukup banyak, namun diantara tulisan-tulisan yang dilacak penulis belum ada yang spesifik yang membahas tentang pendidikan anak dengan mengkaji atas kitab Muqaddimah .

Dengan demikian, signifikansi dan keorisinilan penelitian ini terletak pada adanya pencarian konsep pendidikan anak menurut Ibnu Khaldun yang dikaji langsung dalam kajian kitab Muqaddimah. Suatu kajian yang belum pernah dilakukan sebelumnya. Kajian tulisan ini 
menitik beratkan pada pendidikan anak-anak dalam arti anak yang berumur antara 7-10 tahun, dapat dikatakan anak ketika masih belajar di bangkau sekolah dasar atau tingkatan ibtida'i. Apabila ditinjau dari psikologi perkembangan, usia 6-8 tahun memang masih berada usia dasar. Oleh karena pendidikan yang diberikan dalam keluarga maupun dii lembaga pendidikan formal haruslah kental dengan nuansa pendidikan anak, yakni mengutamakan belajar yang menyenangkan dan menggembirakan bukanlah dengan monoton dan verbal. (http/www, Ummu Syauqi Hafidhul). Jadi pembahasan nanti bukan pada pendidikan anak didik dewasa atau orang yang sudah tua. Namun tidak dipungkiri bahwa hadirnya buku-buku tersebut di atas serta buku-buku lain yang mendukung akan digunakan untuk penyelesaian masalah yang diangkat.

\section{Kerangka Teoritik}

Pendidikan menurut pandangan umum merupakan suatu rangkaian kegiatan yang paling berpengaruh terhadap perubahan prilaku seseorang dan masyarakat. (Abdul Munir Mulkhan, 1993 : 210) Oleh karena itu penyusunan dan penerapan konsep pendidikan Islam dengan sadar yang representatif sesuai dengan misi dan tujuan yang diemban adalah merupakan sesuatu yang sangat vital.

Pendidikan Islam sebagaimana pendidikan modern, dilandasi dengan pemikiran filosofis dalam memecahkan masalah pendidikan. Filsafat pendidikan Islam dalam hal ini berperan memecahkan problematika yang mendasar, melalui pendekatan Islam. Pandangan Islam tentang alam, manusia bahkan seluruh realitas menimbulkan filsafat hidup yang juga merupakan masalah pendidikan. Berkenaan dengan ini maka filsafat pendidikan Islam menentukan tujuan akhir, maksud, obyek, nilai-nilai dan cita-cita yang telah ditentukan lebih dahulu oleh filsafat hidup Islam dan dilaksanakan oleh filsafat pendidikan. (Abdul Munir Mulkhan : 211)

Fenomena yang menjadi masalah dan keprihatinan umat Islam yang muncul ke permukaan sekarang ini adalah karena luas dan kuatnya pengaruh pandangan Barat dalam dunia pendidikan Islam yang dalam banyak hal tidakselaras dengan cita ideal pendidikan Islam. Progresivisme misalnya dalam konsep belajar memandang bahwa manusia sebagai makhluk yang bebas, aktif, dinamis dan kreatif. Dengan akal budinya manusia mampu menciptakan berbagai ilmu pengetahuan, kesenian dan sarana untuk menghasilkan perubahan dan perkembangan (progress). ${ }_{89}$ 
( Imam Barnadib dan Sutari Imam Barnadib, 1992 : 62) Dalam hal ini manusia dididik tanpa didasari nilai-nilai tetapi didasari semata-mata untuk meningkatkan kecerdasan manusia dengan sebebas-bebasnya. Oleh karena itu fungsi pendidikan Islam dengan penanaman akhlak dan etika dan menumbuhkan ruh ilmiah (scientific spirit) sangat penting dan perlu supaya manusia dapat mengontrol dan mengendalikan diri tidak terlepas dari pemikiran yang benar.

Dalam penelitian tokoh dapat dijelaskan dengan menggunakan berbagai kerangka berpikir, yang mengacu kepada fokus penelitian dan tujuan yang hendak dicapai. Dalam penelitian ini digunakan suatu kerangka berpikir yang bersifat makro (kulliy) yang secara sederhana dapat dirumuskan dalam beberapa pernyataan sebagai berikut: (Cik Hasan Bisri, 1998 : 48-49)

1. Pemikiran merupakan suatu pergulatan kreatif di kalangan manusia, dalam hal ini pemikir,dengan mengerahkan daya berpikir dan menggunakan cara berpikir tertentu. Hal itu merupakan refleksi kepedulian terhadap sesuatu yang dipandang penting dalam dan bagi kehidupan manusia.

2. Produk pemikiran mengacu pada aspek normatif dan aspek empirik yang dibingkai oleh kerangka acuan (frame of reference) yang digunakan oleh pemikir. Aspek normatif itu mengacu pada keyakinan, nilai, norma, dan kaidah yang dianutnya. Sedangkan aspk empirik mengacu pada pengalaman, baik pengalaman dirinya maupun pengalaman orang lain dan komunitasnya.

3. Corak pemikiran mencerminkan produk "zamannya”, yang terkait oleh dimensi ruang dan waktu tersebut. Ia merupakan suatu sintesis dari tuntutan kesinambungan dan tuntutan perubahan.

4. Substansi pemikiran mencakup dimensi historis, dimensi definisi situasi, dan dimensi idealisme. Ia bersifat abstrak, oleh karena itu menuntut penjabaran dan operasionalisasi.

\section{Metode Penelitian}

Mengingat obyek penelitian dalam tulisan ini adalah kitab, sedangkan kitab tersebut masuk dalam kategori kepustakaan, maka jenis penelitiannya peneliti masukkan dalam "research kepustakaan" (Sutrisno Hadi, 1993 : 19), maksudnya peneliti mencari informasiinformasi dalam buku-buku atau kepustakaan yang ada kaitannya dengan penelitian ini.

Metode yang digunakan dalam penelitian data adalah penelitian 
kepustakaan (library research) dengan membaca karya-karya Ibnu Khaldun sebagai data primer yaitu kitab Muqaddimah Ibnu Khaldun dan kitab-kitab pendukung yaitu di antaranya kitab al-Ta'rif Ibnu Khaldun wa Rihlatuhu Ghorban wa syirqon dan kitab al- Ibar, dan buku-buku komentar terhadap pemikiran pendidikan Ibnu Khaldun sebagai data sekunder seperti buku karya Fathiyah Hasan Sulaiman yang berjudul Ibnu Khaldun tentang Pendidikan dan buku karangan Fuad Bali dan Wardi yang berjudul Ibnu Khaldun dan Pola Pemikiran Islam.

Dalam menganalisis data, digunakan metode analisis isi (content analyzing). Metode ini dimaksudkan untuk menganalisis makna yang terkandung dalam konsep pendidikan Ibnu Khaldun. Isi yang terkandung dalam penelitian ini kemudian dikelompokkan melalui tahap identifikasi, klasifikasi, dan kategorisasi, kemudian dilanjutkan dengan interpretasi. (Cik Hasan Bisri dan Eva Rufaidah, 2002 : 8)

Dalam menganalisis data juga yang terkumpul digunakan metode komparatif, hal ini digunakan untuk memperoleh kesimpulan dengan menilai faktor-faktor tertentu yang berhubungan dengan situasi yang diselidiki dan membandingkan dengan faktor-faktor lain. (Winarno Surachmad, 1972) Sehingga diharapkan dapat menemukan aktualisasi, relevansi dan kemungkinan pengembangannya yang hadir sebagai solusi alternatif. (Noeng Muhadjir, 1989 : 99)

\section{B.II. BIOGRAFI IBNU KHALDUN}

\section{NAMA DAN ASAL KELAHIRANNYA}

Nama lengkap Ibnu Khaldun yaitu Abdu al-Rahman Ibn Muhammad Ibn Muhammad Ibn Muhammad Ibn al-hasan bin Jabiribn Muhammad Ibn Ibrahim Ibn Khalid Ibn Utsman Ibn Hani Ibn Khattab Ibn Kuraib ibn Ma'dikarib Ibn al-Harits Ibn Wail Ibn Hujar atau lebih dikenal dengan sebutan Abdur Rahman Abu Zayd Muhammad Ibn Khaldun. Abu Zaid Abdul Rahman Ibnu Khaldun dilahirkan di Tunisia pada tanggal 1 Ramadhan 734 H, bertepatan dengan tanggal 27 Mei 1332 M. Keluarganya berasal dari Hadramaut, sebuah daerah pertanian yang cukup subur di kawasan Jazirah Arab sebelah selatan. Mereka dating di Spanyol pada masa pemulaan pendudukan Islam di sana. (B. Lewis, et.Al, 1971 : 825) Nenek moyangnya berasal dari Hadramaut yang kemudian berimigrasi ke Seville pada abad ke VIII setelah semenanjung itu dikuasai Arab Muslim. (Ahmad Syafi'i Ma'arif, 1996 : 11))

Nenek moyang Ibnu Khaldun berasal dari salah satu suku yang 91 
ada di daerah Arab sebelah selatan tepatnya di wilayah Yaman. Ibnu Khaldun adalah cucu keempat dari keturunan Khaldun, yang juga menjadi nama sukunya, nama aslinya Khaldun adalah Khalid, beliau dikenal dengan nama Khaldun karena sesuai dengan kebiasaan orangorang Andalusia dan orang-orang Maghribi yang menambahkan huruf wawu dan nun di belakang nama-nama orang terkemuka sebagai tanda penghormatan dan pengagungan, seperti Hamid menjadi Hamdun, Zaid menjadi Zaidun dan Khalid menjadi Khaldun. (Ali Abd Wahid Wafi, 1985 :4)

Perebutan kembali Spanyol oleh umat Kristen memaksa umat Islam melintasi selat Jibaltar menuju ke Afrika pada tahun $1248 \mathrm{M}$. Tidak begitu lama kemudian Sevilla dirampas kembali oleh Ferdinand III dari Leon dan Gastilla. Keluatga Ibnu Khaldun mengambil keputusan yang bijaksana, mereka menyadari akan akibat buruk yang mungkin terjadi menimpa mereka. Untuk sementara waktu mereka pindah ke Centau dimana pada waktu itu gubernurnya adalah orang dari Hafs. Gubernur tersebut menerima mereka dengan tangan terbuka. Kepala keluarga mereka pada waktu itu adalah al-Hasan Ibn Muhammad Ibn Khaldun, kakek ke empat dari pengarang kitab Muqaddimah. (Osman Raliby : 16) Selanjutnya tidak berapa di Centa, al-Hasan pergi Ke Mekah untuk menunaikan ibadah haji. Setelah kembali dari Mekah ia menetap di Bougie sebagai pegawai tinggi dari Kerajaan Hafsah.

Tempat tinggal mereka sebagian besar di Tunisia. Pada waktu amirnya bernama Abu Zakaria. Dari beliaulah al-Hasan memperoleh bantuan dan perlindungan. Setelah Abu Zakaria meninggal dunia kemudian digantikan anaknya yang bernama Yahya, kemudian saudaranya yang bernama Abu Ishak, selama itu pula Bani Khaldun dapat menikmati kekuasaan dan kekayaan.

\section{C.III. PENDIDIKAN DAN PENGALAMANNYA}

\section{Pendidikan}

Pendidikan Ibnu Khaldun sewaktu kanak-kanak dan remaja tidak berbeda dengan anak-anak lainnya yaitu belajar mengaji, belajar ilmu-ilmu yang berkaitan dengan pemahaman dan penafsiran alQur'an. Beliau belajar dalam bidang tersebut kepada Muhammad Ibn Sa'id Burnail. Selain belajar bahasa Arab kepada ayahnya sendiri, beliau juga menimba ilmu bahasa Arab kepada Syaikh Muhammad Ibn al-Arabi al-Hushairi, Syaikh Muhammad al-Syawwasy al-Zarzali, Syaikh Ahmad 
Ibn al-Qoshor dan Syaikh Muhammad Ibn Bahr. Ilmu hadits dan ilmu hokum Islam diperoleh dari seorang yang cerdik dan masyhur yaitu Syaikh Syamsuddin Muhammad Ibn Jabir Ibn Sultan al-Wadiasyi (12741348 M). Syaikh Muhammad al-Qadir dan Muhammad Ibn Abd as-Salam al-Hawwari. (Nashruddin Thoha, 1979 : 76)

Sebagaimana biasanya sikap anak-anak remaja yang berusia antara 7-13 tahun dimana beliau begitu saja menerima segala apa yang diajarkan kepadanya. Hal itu jga terjadi pada diri Ibnu Khaldun. Namun demikian ketika berusia antara 15 tahun dalam diri Ibnu Khaldun terlihat adanya suatu perubahan pada sikap dan tindak lakunya, seperti diketahui pada masa tersebut merupakan masa yang paling menentukan bagi perkembangan intelektual seorang manusia muda.

\section{Pengalamannya}

Daerah kekuasaan Afrika Utara saat itu dapat diibaratkan seperti sebuah pentas politik dimana setiap orang dapat menyaksikan pergolakan-pergolakan politik yang sangat hebat, saling berebut kekuasaan diantara para warga masyarakat. Hal itu disebabkan runtuhnhya kerajaan al-Muwahhidun dan munculnya Negara-negara kecil serta keamiran-keamiran kecil yang terdiri dari kesultanan Bani Hafs di Tunis, Kesultanan Bani Abdul Wad di Tiemen, dan Kesultanan Bani Marin di Fez dan Marokko. (Ali Abd Wahid Wafi : 167) Ketiga kesultanan itu tetap di dalam pertikaian sesame mereka, sampai kemudian para amir dari kesultanan Bani Hafs dan kesultanan Bani Abdul Wad mampu mengendalikan situasi dan kondisi tersebut serta menempati wilayah masing-masing.

Pada mulanya Ibnu Khaldun bertugas di kesultanan Bani Hafs sebagai karyawan tata usaha untuk menulis surat yang dikeluarkan oleh Sultan. Kemudian di kesultanan Bani Marin, Ibnu Khaldun diangkat oleh Sultan Bani Inan sebagai sekretaris Negara dan juga sebagai anggotaa majlis ilmu pengetahuan. (Osman Raliby : 20) Ibnu Khaldun belum puas dengan jabatan yang diembannya. Beliau ikut mendukung usaha kudeta dalam arti pemberontakan terhadap sultan yang dilakukan oleh Amir Abu Adullah Muhammad, dan raja Bougie yang baru saja dirampas ternyata dijadikan tahanan di Fez. Akhirnya Ibnu Khaldun dimasukkan ke dalam penjara, tepatnya pada tahun $758 \mathrm{H}$. Tak lama kemudian Ibnu Khaldun dibebaskan dari penjara oleh Sultan Abu Inan. Pada tahun 759 H/1358 M, setelah mempersembahkan kepada Sultan 700 syair yang 93 
berisi memuji kehebatan Sultan. (Nashruddin Thoha : 78)

Selanjutnya pada pertengahan tahun $766 \mathrm{H}$, beliau meninggalkan Granada untuk kembali ke Bijayah. Dengan senang hati Sultan Bijayah menhyambut kedatangannya dan tidak lama kemudian Ibnu Khaldun diangkat menjadi Perdana Menteri sebagaimana dijanjikan sewaktu sama-sama dipenjara.

Dengan demikian Ibnu Khaldun telah menggapai impiannya untuk memegang pangkat dan kedudukan tertinggi pada pemerintahan. Disamping itu beliau juga memberikan kuliah di Masjid Raya, tugas yang pernah terlupakan kapanpun dan dimamanpub selama hidupnya. Selama kurang lebih empat tahun berpetualangan serta memperoleh setumpuk pengalaman-pengalaman politik, Ibnu Khaldun merasa jenuh terhadap terhadap persoalan politik, sebagai wujudnya beliau memutuskan untuk menetap di Qol'at Ibn Salamah, yaitu sebuah puri di desa dalam propinsi Iran. Disanalah beliau menghirup udara kehidupan yang segar dan tenang. Hari-harinya dipergunakan untuk studi menelaah dan mengarang kitab. Ketika usia 45 tahun penyelidikan dan studinya sudah cukup matang. Selama seperempat abad beliau berkecimpung di dalam dunia politik, pindah dari kesultanan atau beralih ke kesultanan yang lainnya dengan jabatan yang tergolong cukup tinggi. Hijrah dfari Maghribi ke Andalusia, kota dan kabilah telah dilalui serta dikarunginya. (Osman Raliby : 30)

kegiatan merenung, kontemplasi dan berpikir, menulis serta mengarang beliau aktifkan, sehingga dapat membuahkan hasil yang berupa ilmiah tentang sejarah umat manusia yang dinamakannya kitab al-bar wa Diwan al-Mubatada wa al-Khabar fi Ayyam al-Araby wal Ajami wal Bar Bar wa Manasrahum min Dzawi alp-Sulthan alAkbar. (kitab tentang Ibarat-ibarat dan catatan sejarah terdahulu dan kemudian. Memperbincangkan peristiwa-peristiwa poilitik dari bangsabangsa Arab, Asing dan Bar-Bar dan raja-raja besar yang hidup di masa mereka) disingkat dengan kitab al-Ibar saja, sebagai pendahuluan dari kitab sejarah itu maka dikarangnya kitab Muqaddimah.

Muqaddimah itu selesai dikarang oleh beliau pada pertengahan tahun 1377 M dalam jangka waktu lima bulan. Ibnu Khaldun merasa sangat sukses dengan hasil ciptaannya itu. (Osman Raliby : 30) Kemudian Ibnu Khaldun berkata: "Saya telah menyelesaikan kitab Muqaddimah itu dengan cara yang aneh, saya seperti diilhami, sehingga kata-kata dan pikiran-pikiran seperti mengalir saja ke otakku. 
Begitu beliau sampai ke Kairo para ulama dan pendidik khususnya dengan antusias menyambut kehadiran beliau. Mereka mengharapkan adanya tambahan ilmu dari penulis kitab terkenal itu. Tanpa diundang banyak budayawan berkumpul mengelilinginyauntuk mendengarkan ceramahnya serta menyerap dan mencerna ilmu-ilmu khususnya yang berkenaan dengan pembahasan metode dan pemikiran dan konsep yang dituangkan di dalam kitabnya Muqaddimah, oleh karena itu beliau mengambil tempa di aula al-Azhar sebagai tempat kuliahnya. (Osman Raliby : 79)

\section{Karya-Karya Ibn Khaldun}

Sebagaimana telah dikemukakan bahwa salah satu kelebihan Ibnu Khaldun disamping menguasai berbagai disiplin ilmu, juga telah berhasil menuangkan ide dan gagasannya dalam berbagai bidang ilmu yang dikuasainya ke dalam bentuk tulisan-tulisan. Beliau termasyhur sebagai ilmuan besar adalah karena buah karya beliau Muqaddimah sebuah kitab pengantar kitab Al-'Ibar. Karya monumentalnya tersbut telah membikin para sarjana baik Timur maupun Barat begitu mengaguminya. Karyakarya tersebut merupakan perpaduan kegeniusannya dengan kekayaan pengalamanny, kematangan pribadi, kekuatan hirrahnya, ketajaman menganalisa dan ketangkasan dalam memecahkan masalah sehingga mampu menemukan terobosan baru. (Ali Abd Wahid Wafi : 71)

Karya-karya Ibnu Khaldun itu adalah:

\section{a. Muqaddimah}

Muqaddimah ini merupakan kitab pertama dari kitab al-'Ibar yang terdiri dari bagian muqaddimah (pengantar) dari kitab satu. Kitab Muqaddimah oleh orang Barat disebut dengan prolegomena. Kitab pengantar yang panjang inilah yang merupakan inti seluruh persoalan serta kitab tersebutlah yang mengangkat nama Ibnu Khaldun begitu harum. Adapun isi kitab Muqaddimah tersebut adalah Ibnu Khaldun mengawali ulasannya secara detail tentang nilai-nilai sejarah dan bentuk-bentuknya, kesalahan-kesalahan yang dilakukan oleh para ahli sejarah di dalam mencatat tanggal dan peristiwa, baik karena disengaja dengan maksud-maksud tertentu atau karena semata-mata karena kecorobohan yang tak disadari. Uraian ini disertai dengan contoh-contoh dan penjelasan yang menarik. Ibnu Khaldun juga menekankan pentingnya mengetahui fakta-fakta dan peristiwaperistiwa yang sesuai dengan hukum-hukum ilmu sosiologinya. 
b. al-'ibar wa Diwan al-Mubtada' wa al-Khabar fi Ayyam al-Arab wa al-Ajam wa al Babar wa Man Ashrohum min Dzawi al-Sultan al-Akbar

Kitab ini kemudian terkenal dengan sebutan al-'Ibar. Kitab ini terdiri dari tiga kitab. Kitab pertama adalah Muqaddimah, sebagai pengantar atau jilid satu dan berisi tentang masyarakat dab cirricirinya yang hakiki pemerintahan, mata pencaharian, penghidupan, keahlian, kealaman dan ilmu pengetahuan dengan segala sebab dan alasannya. KItab kedua meliputi jilid kedua, ketiga, keempat dan kelima. Kitab ini mengulas tentang sejarah bangsa Arab, generasigenerasi mereka dan dinasti-dinasti dari terciptanya alam sampai sekarang. Kitab ini juga menceritakan sekilas tentang bangsabangsa yang terkenal seperti Ponteam, Syiria, Persia, Yahudi, Yunani, Romawi, Turki dan Eropa. Kitab ketiga terdiri dari jilid keenam dan ketujuh yang menerangkan sejarah bangsa Barbar dan Zanathayang merupakan bagian dari mereka khususnya kerajaan dan Negara Maghribi. (Zainal Abidin Ahmad, 1979 : 254) Dan dipungkasi dengan auto biografi pengarangnya.

c. al-Ta'rif Ibnu Khaldun wa Rihlatuhu Ghorban wa Syirqon

Kitab ini oleh orang Barat disebut Autobiografi, (MA. Enam, 1979 : 134) dan kemudian disingkat al-Ta'rif. Al-Ta'rif merupakan bagian akhir dari kitab al-Ibar yang dalam beberapa hal mengulas tentang kehidupan Ibnu Khaldun. Beliau menulis autobigrafinya secara sistematik dengan menggunakan metode ilmiah, terpisah dalam beberapa hal tetapi saling terkait antara satu dengan yang lainnya

Dari sinilah banyak buah karya Ibnu Khaldun ini hanya sebagian yang sampai kepada kita, sehingga terkesan adanya kegterputusan antara generasi muslim masa lampau dengan masa sekarang.

\section{D.IV. DASAR DAN TUJUAN PENDIDIKAN ANAK MENURUT IBNU KHALDUN}

Menurut Ibnu Khaldun bahwa ilmu pendidikan bukanlah suatu aktifitas yang semata-mata bersifat pemikiran dan perenungan, serta jauh dari aspek-aspek pragmatis di dalam kehidupan, tetapi ilmu pengetahuan (pendidikan) tidak lain adalah dua buah fenomena sosial, termasuk fenomena sosial yang menjadi ciri masyarakat manusia. (Fathiyah Hasan Sulaiman : 33) 
Kehidupan dan semua aktifitas yang merupakan fenomena sosial dari masyarakat haruslah mempunyai dasar. Dasar pendidikan anak menurut Ibnu Khaldun tidak lepas dari dasar pendidikan Islam. Pendidikan Islam itu didasarkan pada kaedah hukum dalam al-Qur'an dan al-Hadits.

Athiyah al-Abrasyi menandaskan bahwa dasar pendidikan Islam adalah al-Qur'an dan al-Hadits, yaitu bahwa pendidikan Islam dibangun atau didasarmkan atas kaidah hukum yang ditulis dalam alQur'an dan atas sabda Rasulullah. (Athiyah Al-Abrasyi, tt, 284) Dasar pendidikan anak menurut Ibnu Khaldun adalah al-Qur'an yakni dalam menemukan gagasan-gagasan di bidang pendidikan anak, karena alQur'an memberikan pandangan yang mengacu pada kehidupan di dunia dan asas-asas dasarnya memberi petunjuk kepada pendidikan Islam. (Abdurrahman Saleh Abdullah, 1994 : 20) Dalam meneliti fenomena yang ada di dalam masyarakat Ibnu Khaldun menggunakan metode ilmiah yaitu dengan cara observasi dan berpikir secara logika, sehingga dengan penelitiannya memunculkan penemuan tentang teori hubungan sebab akibat atau disebut sunnatullah dan menciptakan teori-teori dan konsep-konsep baru dalam pendidikan anak.

Al-Qur'an sebagai rujukan dan acuan pendidikan anak maka muncullah gagasan baru dalam pendidikan anak yang sesuai dengan kondisi dan situasi yang ada di dalam masyarakat, melalui pengamatan dan kajian secara empiris yang dilakukan oleh Ibnu Khaldun di negaranegara Islam yang ada di Afrika dan Andalusia.

Ibnu Khaldun sendiri menyebutkannya dalam kitab Muqaddimahnya:

اعلم ان تعليم الو لد ان للقر ان شعار الدين اخذ به اهل الملة و درجو ا عليه في جميع

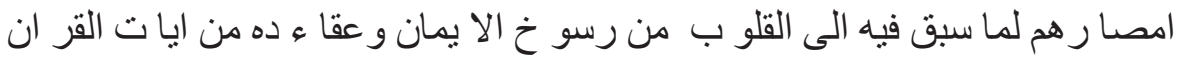

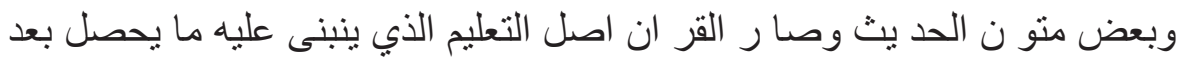

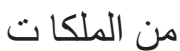

Artinya: "Bahwa sesungguhnya mengajar al-Qur'an kepada anak-anak itu merupakan syiar agama atau symbol agama. Ahli agama mengambil dan memasukannya dalam semua masa-masa mereka. Hal itu akan mengilhami hati dengan menancap dan masuknya iman dan akidahnya dari ayat-ayat al-Qur'an dan sebagian dari matan hadits dan al-Qur'an menjadi dasar pengajaran dan fondasi semua keahlian yang diperoleh kemudian. (Abdurrahman Saleh Abdullah, 1994 : 20) 
Meskipun dalam pernyataan Ibnu Khaldun tidak disebutkan secara jelas, namun sudah tersirat di dalamnya bahswa al-Qur'an menjadi dasar dari ta'lim (pengajaran). Karena al-Qur'an dan al-Hadits merupakan dasar agama, maka Ibnu Khaldun juga mengisyaraktkan kembali pada pentingnya penghafalan pada al-Qur'an. Ibnu Khaldun mengatakan dalam Muqaddimahnya:

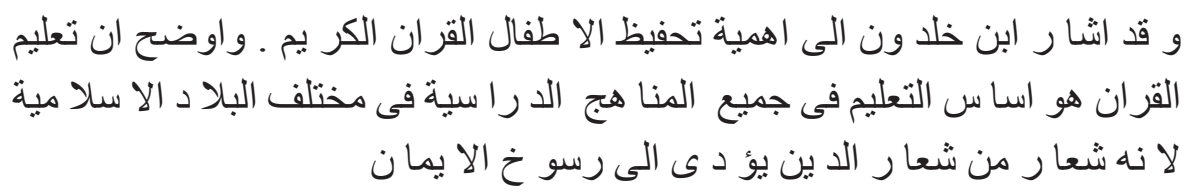

Artinya: "Ibnu Khaldun mengisyaratkan pada pentingnya penghafalan alQur'an bagi anak-anak, beliau menjelaskan bahwa pengajaran al-Qur'an dalam semua system pengajaran pada berbagai negara-negara Islam, karena al-Qur'an merupakan syiar agama yang dapat mendatangkan pada kuatnya iman" (Athiyah Al-Abrasyi : 165)

Dari pendapat dan pernyataan Ibnu Khaldun di atas dapat ditarik kesimpulan bahwasannya al-Qur'an merupakan dasar pendidikan yang juga merupakan dasar pendidikan anak.

Adapun tujuan pendidikan anak menurut konsep Ibnu Khaldun juga tidak disebutkan secara langsung, tetapi dapat diungkapkan bahwa sesungguhnya tujuan pendidikan yang bersumberkan al-Qur'an adalah untuk mencapai tujuan pembentukan akidah atau keimanan yang mendalam pada diri anak dan menumbuhkan dasar-dasar mulia jalan agama yang diturunkan untuk mendidik jiwa manusia serta menegakkan moral dan akhlak yang membangkitkan pada perbuatan baik, (Ali AlJumbulati, 1994 : 58) dan itu merupakan tujuan yang paling pokok dan terpenting dalam pendidikan anak.

Hal yang demikian dikatakan Ibnu Khaldun dengan tegas dalam kitabnya Muqaddimah:

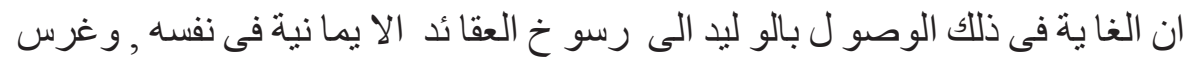

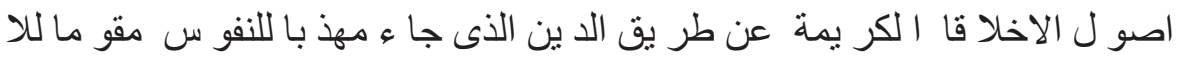
خلا ق با عثا للخير Artinya: "Bahwa sesungguhnya tujuan dari hal itu adalah menanmkan anak dan memasukkan akidah keimanan dalam dirinya, dan menanamkan dasar-dasar akhlak yang mulia dari jalan agama yang membersihkan 
pada jiwa, yang menegakkan akhlak dan membangkitkan kebaikan" (Athiyah Al-Abrasyi : 258)

Pernyataan di atas didukung oleh sebagian tokoh pendidikan misal al-Qabisi, Ibnu Sina dan juga alp-Ghazali, yang menyebutkan bahwa sebagian dari mereka ada yang menanamkan dengan pendidikan moral dan akhlak atau menganjurkan rasa keagamaan atau menetapkan kaidah yang tertentu. (Athiyah Al-Abrasyi, tt : 30)

Dari pernyataan di atas dapat ditarik kesimpulan bahwa tujuan pendidikan anak menurut Ibnu Khaldun adalah penanaman akidah / keimanan dan akhlak yang mulia pada diri anak. Hal ini berarti bahwa anak lebih ditekankan pada tujuan ilmu agama, kemampuan agama dan akhlak yang baik dalam memberikan pengaruh yang besar untuk perkembangan anak sampai usia dewasa. Hal ini tersirat dalam pernyataan Ibnu Khaldun dalam kitabnya Muqaddimah di atas tadi. Pendidikan agama dan pendidikan akhlak (budi pekerti) tidak ditumbuhkan kecuali sejak kecil atau usia dini, khususnya melalui kehidupan keagamaan yang saleh dan utama yang dihayati oleh keluarga itu yang dilakukan oleh anak di rumah, sekolah dan dalam masyarakat. (Fathiyah Hasan Sulaiman: 73)

Jadi apabila dianalisa secara mendalam bahwa tujuan pendidikan anak menurut konsep Ibnu Khaldun adalah membentuk anak agar menjadi orang dewasa yang berkepribadian baik, berbudi luhur, berakhlak mulia melalui nilai pendidikan dalam al-Qur'an.

Konsep Ibnu Khaldun sesuai dengan konsep pendidikan Ibnu Sina yang menyatakan bahwa pendidikan akhlak (budi pekerti) ini merupakan tujuan utama dari pendidikan pada umumnya, sebab tujuan pendidikan itu adalah membentuk orang yang berakhlak mulia disamping membentuk kepribadian yang kuat di kalangan anak-anak.

Membentuk kepribadian baik dan anak yang mempunyai akhlak mulia itu merupakan tujuan pokok, utama dan inti dari tujuan pendidikan anak menurut konsep Ibnu Khaldun, namun ketika anak sudah menginjak remaja dan dewasa maka tujuan pendidikan anak harus ditambah dengan tujuan hidup anak yaitu dia harus mempunyai alat atau keahlian yang dipelajari dari berbagai ilmu pengetahuan untuk dia di masa mendatang dalam arti untuk giat beraktifitas dan bekerja dalam mencukupi kehidupannya dan keluarganya.

Maka dapatlah dianalisa dengan menyimpulkan bahwa tujuan 99 
menurut konsep Ibnu Khaldun ketika anak menginjak dewasa yaitu memberikan kesempatan kepada pikiran untuk aktif dan bekerja, karena aktifitas ini sangat penting bagi terbuka pikiran dan kematangan anak kemudian kematangan ini dapat memberikan manfaat pada masyarakat, memperoleh berbagai ilmu pengetahuan sebagai alat untuk membantunya hidup dengan baik di dalam masyarakat maju dan berbudaya, dan memperoleh lapangan pekerjaan yang digunakan untuk memperoleh rizki.

\section{E.5. RELEVANSI TUJUAN PENDIDIKAN ANAK DENGAN PENDIDIKAN DEWASA INI}

Berbicara masalah pendidikan merupakan suatu kajian yang cukup menarik, karena pemahaman makna tentang pendidikan sendiripun juga beragam. Perlu diketahui bahwa banyak sekali istilahistilah dalam pendidikan itu sendiri, seperti pengajaran, pembelajaran, paedagogi, pendidikan pelatihan, dan lain sebagainya. Semua itu dapat kita jumpai dalam buku-buku yang mengkaji tentang pendidikan.

Pendidikan menurut Marimba adalah bimbingan atau pimpinan secara sadar oleh pendidik terhadap perkembangan jasmani dan rohani anak didik menuju terbentuknya kepribadian yang utama. (Ahmad D. Marimba, 1989 : 19) Dalam pendidikan yang dijelaskan tersebut di atas, bahwa dalam pendidikan terdapat beberapa unsur: 1) Usaha (kegiatan) yang bersifat bimbingan dilakukan secara sadar.2) Ada pendidik, pemimpin atau penolong, 3). Ada peserta didik, anak didik, 4).Bimbingan itu mempunyai dasar dan tujuan 5) Dalam usaha itu terdapat alat-alat yang pergunakan.

Dari pemaknaan tersebut, dinyatakan bahwa pendidikan terbatas kepada pengembangan anak didik oleh pendidik. Jadi terdapat pengaruh dari orang per orang atau manusia lain secara sadar. Melihat kondisi pendidikan dewasa ini sebagaimana telah didiskripsikan, maka peniruan terhadap konsepsi pendidikan barat harus dihentikan, karena tidak sesuai dengan cita-cita Islam. Sebaliknya merupakan keniscayaan untuk mencari paradigma pendidikan yang paling sesuai dengan citacita Islam.

Dalam konteks ini, menjadi tanggung jawab moral bagi pakar muslim untuk membangun teori Islam sebagai paradigma ilmu pendidikan. Paradigma ilmu pendidikan yaitu penggunaan nilai-nilai Islam sebagai sudut pandang secara menyeluruh mengenai persoalan- 
persoalan yang berkaitan dengan gejala-gejala pendidikan dalam rangka menyusun teori pendidikan.

Dalam wacana ilmiah, setidaknya dapat dikemukakan beberapa alasan mendasar tentang pentingnya realisasi paradigma tersebut, pertama Islam sebagai wahyu Allah yang merupakan pedoman hidup manusia untuk mencapai kesejahteraan hidup di dunia dan akherat, baru bisa dipahami, diyakini, dihayati dan diamalkan setelah melalui pendidikan. Disamping itu secara fungsional, Nabi Muhammad Saw. sendiri diutus Allah sebagai pendidik umat manusia. Oleh karenanya bukan sesuatu yang mengada-ada bila Islam diangkat sebagai paradigma ilmu pendidikan. Kedua, ilmu pendidikan sebagi ilmu humaniora juga termasuk ilmu normatif, sebab ia terikat dengan norma-norma tertentu. Dini nilai-nilai Islam sangat memadai untuk dijadikan sentral norma dalam ilmu pendidikan. Ketiga, dalam menganalisa dan memecahkan berbagai permasalahan pendidikan, para ahli pendidikan ini cenderung mengambil sikap seakan-akan semua permasalahan pendidikan, baik mikro maupun makro diyakini dapat diterangkan dengan teori-teoriatau filsafat pendidikan barat, padahal yang disebut terakhir tadi bersifat sekuler. Oleh karena itu nilai-nilai ideal Islam mestinya akan lebih sesuai untuk menganalisa secara kritis fenomena kependidikan.

Paradigma yang ditawarkan olel Muhajir sangat teoritik dan filosofik. Karenanya telaah ulang lebih cermat diperlukan untuk ditampilkan pada taraf telaah substansial ilmu pendidikan, baik yang teoritk maupun yang terapan dan teknologik.

Bahwa konsepsi pendidikan barat dewasa ini merupakan manifestasi dari persepsi peradaban barat terhadap realitas dunia. Maka meniru dan mengikuti mereka berarti menjadikan kaum muslimin budak bagi peradaban barat dan pandangan dunianya. Maka pendidikan Islam harus mampu mengantisipasi kebutuhan dan tantangan umat Islam di masa datang. Dalam konteks konseptual-keilmuan, harus bisa mengembangkan dan menemukan konstruk paradigma pendidikan yang berangkat dari pandangan dunia Islam.

Mengkaji tentang tujuan pendidikan Islam tidak dapat dilepaskan dari upaya memahami konsep dasar pendidikan Islam yang secara hakiki digali dan dikembangkan dari al-Qur'an dan as-Sunnah, di samping merujuk kepada ijtihad para ahli. Keduanya merupakan tiang penyangga yang memelihara esensi dan tujuan-tuan fundamentalnya, baik yang harus dilestarikan maupun yang menghendaki kreasi terus 
menerus. Pendidikan dalam hal ini ditujukan untuk mempersiapkan manusia yang baik dan benar, yang mengabdi kepada Allah dalam pengertian yang sesungguhnya, serta memiliki kemauan dan kemampuan dalam membangun struktur kehidupan duniawinya sesuai dengan syariat dan melaksanakannya untuk menopang keimanannya. Kedua tujuan ini selaras dengan tujuan penciptaan manusia yang berfungsi sebagai hamba Allah dan berperan sebagai khalifah-Nya.

Pendidikan merupakan usaha dan kegiatan yang sarat dengan tujuan. Kedudukan tujuann dalam pendidikan cukup strategis, karena selain memberikan panduan tentang karakteristik manusia yang ingin dihasilkan oleh pendidikan tersebut, sekaligus pula menentukan arah dan langkah-langkah dalam melakukan seluruh kegiatan dan proses penyelenggaraan pendidikan. Oleh karena itulah berbagai pembahasan dan penelusuran terhadap suatu sistem pendidikan seringkali mengalami ketidakberhasilan disebabkan mengabaikan kajian terhadap konsep-konsep tujuan pendidikan yang dicanangkannya. Hal itu berarti bahwa untuk memahami konsep-konsep pendidikan Islam, tentulah diperlukan pemahaman yang memadai tentang tujuan pendidikan Islam sebagaimana disajikan pada uraian-uraian berikut.

Telah dikatakan di depan bahwa pendidikan merupakan suatu usaha dan kegiatan yang sarat dengan tujuan. Kedudukan tujuan dalam pendidikan cukup menentukan, karena selain memberikan panduan tentang karakteristik manusia yang ingin dihasilkan pendidikan, sekaligus pula memberikan arag dan langkah dalam melakukan seluruh kegiatan pendidikan.

Dalam hubungan ini, Muhammad Qutb, guru besar pengkajian Islam pada Universitas King Abdul Aziz Mekah ketika mengawali tulisannya dalam buku Minhaj al-Tarbiyah al-Islamiyyah segera mempertanyakan, "Apakah yang paling ditekankan dalam sistem pendidikan Islam, saranakah atau tujuan?". (Muhammad Qutb, 1983 : 11) Meskipun Qutb tidak memberikan jawaban tuntas atas pertanyaan yang diajukannya itu tetapi jelas terlihat bahwa dia memandang tujuan pendidikan merupakan unsur strategis yang lebih penting dari pada sarana, karena sarana itu akan selalu mengalami perubahan dari masa ke masa dari generasi ke generasi.

Demikian pentingnya kedudukan tujuan dalam pendidikan Islam menyebabkan banyak pakar yang menolak pendidiknan tanpa tujuan akhir yang jelas. Atas dasar itulah pendidikan Islam menolak sikap yang 
dikembangkan John Dewey (1859-1952) seorang filosof pendidikan Amerika yang keberatan menerima adanya suatu tujuan final dalam pendidikann. Dalam hal ini Dewey menganggap bahwa orang-orang yang membuat tujuan final bagi pendidikan telah meletakkan "sesuatu" yang lain di luar aktivitas pendidikan dan bukan berada di dalamnya. (John Dewey, 1980 : 121)

Akan halnya Omar Muhammad al-Toumy al-Syaibani, guru besar Falsafah Pendidikan Islam pada Universitas Tripoli Libya, meskipun tidak keberatan terhadap "pertumbuhan sebagai bagian dari tujuan pendidikan, tetapi makna pertumbuhan yang dimaksudkan itu sebaiknya diarahkan kepada pertumbuhan yang dikehendaki dan bukan pertumbuhan yang bebas tak terkendali, melainkan dengan memberi isi dan makna pada pertumbuhan itu akan nilai-nilai yang bermuatan spiritual dan akhlak di dalam seluruh proses dan aktivitas pendidikan yang dilaksanakan. (Omar Muhammad at-Toumy as-Syaibani, 1979 : 410)

Kritik-kritik yang dikemukakan para ahli pendidikan Islam terhadap Dewey itu menunjukkan urgensi tujuan pendidikan. Jenis tujuan apapun yang hendak digunakan pendidikan Islam baik tujuan perantara maupun sementara, maupun tujuan-tujuan khusus tidak boleh lepas dari inti tujuan idealnya yang senantiasa inheren dengan iman dan amal saleh sebagai nilai-nilai badi yang menjadi tujuann fundamental dalam pendidikan Islam.

Sebagai contoh, bahwa Islam jelas-jelas keberatan menerima tujuan pendidikan yang dikemukakan oleh kalangan Humanistic Mental Discipline yang hanya bertumpu untuk mewujudkan manusia intelek dan cerdas. Konsep ini berakar dari pemikiran klasik Plato dan Aristotels dan dikembangkan lagi oleh para Humanis abad ke 20 seperti Robert M. Hutchins dan Mortimer J.Adler. (Morris L.Bigge, 1994 : 29) Mereka lebih mengagungkan manusia sebagai makhluk yang terdiri atas mind dan organisme biologis yang sama- sama memiliki otot-otot yang khas. Mind sebagai substansi non fisik mempunyai kekuatan ntuk mengingat, ada keinginan, ketetapan hati dan lain sebagainya yahg apabila dilatih secukupnya akan dapat beroperasi dengan sendirinya. (Morris L.Bigge : 24) Dengan demikian maka tujuan terttinggi suatu pendidikan adalah mengolah Mind atau intelek agar mencapai taraf yang tinggi.

Senada dengan itu, John Locke juga mengemukakan tujuan pendidikan untuk membentuk manusia gentlean yang mengutamakan kepribadian berdasarkan pengetahuan. Karena itu seprti dikatakan 
Sutan Zanti Arbi bahwa tujuan pendidikan John Locke hanya sematamata untuk mengembangakn kemampuan bernalar. (Sutan Zanti Arbi, 1988 : 97) Memang Locke berusaha mengharmoniskan pendidikan rohani dan jasmani, tetapi pendidikan rohani yang dimaksudkannya bukan bersumber dari ajaran agama yang diwahyukan Tuhan, melainkan berasal dari hasil pemikiran manusia. Locke tidak mengakui Tuhan berdasarkan pemberitaan wahyu, tetapi Tuhan wajib dipercayai dengan jalan rasio atau akal. Karena itu Locke tidak bisa menerima ajaran moral yang bersumber dari ktab suci. Ia hanya mengajarkan moral berdasarkan kemanfaatan praktisnya. (Agus Sujono, 1978 : 19)

Seperti juga Locke, J.J. Rousseau juga menekankan tujuan pendidikan untuk membentuk manusia bebas dan merdeka dari tekanan manapun maupun ikatan serta tidak untuk tujuan tertentu, apakah itu menjadikan peserta didik menjadi seorang beragama atau menjadikan warga masyarakat dan warga negara yang baik, juga tidak untuk suatu jabatan melainkan semata-mata menjadi seorang individu yang bebas. Rousseau dalam hal ini hanya percaya pada alam. Alamlah yang berhak memberikan pendidikan kepada peserta didik secara bebas dan alamiah. Karena itu ia membuat gagasan agar peserta didik dijauhkan dari masyarakat karena hal itu dapat merusak kepribadian peserta didik yang telah diciptakan Tuhan dalam keadaan baik sejak pertama kalinya. Menurut pendapatnya, peserta didik pada dasarnya baik; dan masyarakat itulah yang kurang baik. Kebaikan alamiah manusia itu menurut Rousseau hanya dapat dipelihara oleh pendidikan dari alam, dan bukan dari masyarakat. (Djakfar Siddik, 2005 : 19-30)

Rousseau percaya bahwa setiap manusia mempunyai tiga guru, yaitu "alam", "orang-orang" dan hal-hal atau benda-benda. Alam mengembangkan daya-daya dan organ-organ yang terdapat dalam diri manusia. Sedangkan pengembangan maknanya merupakan pendidikan yang diberikan manusia. Kepandaian dalam memahami obyek-obyek merupakan pengaruh didikan benda-benda. Apabila ketiga guru tersebut menghasilkan tujuan yang sama maka manusia akan mencapai tujuan yang benar.

Apakah sebenarnya tujuan pendidikan yang benar itu? Jawabannya adalah nature (alam). Rousseau mendefinisikan nature sebagai sifat bawaan dan bakat-bakat asli yang belum dimodifikasi oleh pengaruh kebiasaan-kebiasaan yang lain. (Djakfar Siddiq : 156)

Oleh karena pendidikan dari orang-orang dapat mengubah sifat 
bawaan asli manusia, maka haraan Rousseau lebih bertumpu pada dua guru lainnya, alam dan benda-benda dengan tetap menjaga agar pendidikan dari orang-orang berada pada profil terendah. Karena itu Rousseau menawarkan suatu pendidikan seperti yang diperbuatnya kepada Emile, yang dijauhkan dari lingkungan orang-orang dengan memindahkannya ke daerah pedalaman dengan bantuan tutor yang terlatih. Dengan cara seprti itu peserta didik, menurut pendapatnya, terbebas dari kompleksitas dan kotradiksi-kontradiksi masyarakat yang dapat menariknya pada suatu keadaan dan keinginan yang tak sesuai dengan bawaan alamiahnya.

Memang, dasar berpijak Rousseau dalam membangun konsep pendidikannya kelihatannya mempunyai nilai positif agar sifat dasar alamiah manusia yang datang dari Tuhan itu tidak sampai rusak di tangan orang-orang. Tetapi karena Rousseau menjauhkan peserta didik dari masyarakat maka nilai yang positif tadi telah kehilangan maknanya.

Rousseau berbuat seperti itu agar sifat alamiah peserta didiknya dapat berkembang secara alamiah yang dapat mewujudkannya menjadi "orang" dan bukan menjadi seorang pengacara atau menjadi tentara dan polisi, bahkan tidak akan menjadi seorang pendeta, tetapi yang paling utama seperti yang terlihat dalam pernyataannya di atas, peserta didiknay akan menjadi manusia.

Rousseau tidak ingin peserta didiknya menjadi "orang lain", tetapi tetap menjadi dirinya sebagai individu yang bebas dalam menentukan masa depannya sendiri. Untuk memenuhi obsesinya itu, tampaknya Rousseau telah mengorbankan nilai pendidikan sosial yang memungkinkan peserta didiknya kehilangan rasa sosialnya karena dijauhkan dari kehidupan bermasyarakat. Dengan demikian tujuan pendidikan Rousseau hanyalah untuk menciptakan individu yang bebas dan alamiah, termasuk menjadi penganut agama alamiah (natural religion). Sebagai seorang penganut agama alamiah, Rousseau tidak percaya terhadap ajaran yang diwahyukan. Dia hanya bertuhan melalui pengalamannya saja. Meskipun begitu Rousseau tidak setuju terhadap ateisme, karena menurut pendapatnya seorang ateis bukanlah seorang yang jujur sekurang-kuranya terhadap dirinya sendiri. (Djakfar Siddiq : 156)

Jadi kalau dianalisa bahwa tujuan pendidikan anak menurut Ibnu Khaldun itu masih relevan dengan pendidikan dewasa ini yang dipelopori oleh aliran pembaharuan pendidikan yang ditokohi oleh 105 
Fouerster, seorang ahli pendidik dari Jerman dengan sekolah kerjanya.

Ibnu Khaldun mengatakan bahwa penanaman akhlak dan moral yang baik pada anak itu dimulai sejak usia dini dengan mempelajari al-Qur'an dan syi'ir-syi'ir yang bernilaikan dan berisikan cerita-cerita atau kisah para tokoh dan pahlawan, agar pelajaran itu membekas pada kejiwaan anak dan untuk menjadikan kepribadian yang baik dan nantinya setelah dewasa menjadi manusia yang baik dan berbudi luhur dan hal ini adalah pendidikan iman dan akhlak yang ditanamkan Ibnu Khladun pada anak.

Ibnu Khaldun tidak menerangkannya secara panjang lebar, namun yang terpenting dalam mendidik anak tujuan utama dan pertama adalah pendidikan akhlak dan keimanan, kemudahan dilanjutkan dengan tujuan akal atau intelektual.

Itulah pentingnya Ibnu Khaldun pertama kali ditanamkan pendidikan adalah pendidikan keimanan dan akhlak, baru setelah itu anak dapat dibimbing dan diarahkan dengan pendidikan kecerdasan, keaktifan, kreatifitas sehingga anak dapat tumbuh dengan baik dan sesuai dengan perkembangan anak. Saya kira konsep Ibnu Khaldun mengenai pendidikan anak masih dan sangat relevan dengan konsep pendidikan anak dewasa ini.

Selanjutnya dalam mengajarkan al-Qur'an maka tujuan yang dharapkan adalah agar anak mampu membaca dan menceritakan alQur'an, juga anak nantinya akan menghafal dan memahami makna beberapa kutipan terpilih atau surat yang penting. Begitu juga dalam mengajarkan al-hadits, diharapkan anak-anak-anak akan belajar mengenai kehidupan dari Rasulullah nabi Muhammad Saw. (Ali Ashraf, 1993 : 128-129) dan para sahabatnya serta nabi-nabi lainnya.

Dalam mengajarkan syi'ir yang didalamnya mengandung cerita, kisah yang menarik dari para tokok kaum muslim, diharapkan anak mempunyai rasa perhatian dan simpati kepada teman-teman mereka, ketaatan kepada orang tua atau yang lebih dewasa. Juga dalam pengajaran bahasa Arab anak diberikan penguasaan kata-kata dasar dan struktur bahasa Arab, sehingga dalam pelajaran bahasa Arab selajutnya tidak mengalami kesulitan. (Ali Ashraf : 118)

Selanjutnya yang terakhir adalah anak-anak diharapkan mempelajari makna atau arti dari nilai-nilai Islam melalui isi, bahasa dan contoh dari matematika dasar, yang nantinya digunakan dan dipraktekkan dalam kehidupan mereka. (Ali Ashraf : 129) 
Disinilah letak keagungan konsep Ibnu Khaldun tentang pendidikan Islam yang mengkhususkan pada pendidikan anak, yang sebagian besar konsep-konsep pendidikan beliau masih relevan dengan konsep pendidikan anak dewasa ini. Begitu juga tentang materi dan metode pendidikan anak banyak yang relevan dengan pendidikan anak dewasa ini, apalagi Ibnu Khaldun adalah seorang tokoh pendidikan yang sedikit berbeda dengan tokoh pendidikan Islam sebelumnya.

\section{F.6. KESIMPULAN}

Dari uraian di atas dapat diambil kesimpulan sebagai berikut :

a. Konsep pendidikan anak menurut Ibnu Khaldun dalam kitab Muqaddimah didasarkan pada Al-Qur'an, sehingga pendidikan yang digagas dan dicetuskan oleh Ibnu Khaldun berpijak pada ketentuan Al-Qur'an baru kemudian di landasi dengan ketentuan intelektual dan akal.

b. Tujuan pendidikan anak menurut pemikiran Ibnu Khaldun dalam kitab Muqaddimah adalah membentuk anak supaya memiliki akhlak yang mulia, kepribadian yang baik dan tangguh, memiliki malakah atau ketrampilan dan menguasai ilmu-ilmu agama (naqliyah) dan ilmu-ilmu umum (aqliyah) untuk eksistensi kelangsugan hidup mereka.

c. Konsep pendidikan anak menurut Ibnu Khaldun dalam kitab Muqaddimah ternyata masih relevan dengan tokoh-tokoh pendidikan Barat, misalnya Locke, J.J. Rousseau Locke, , Fouerster, dan John dewey, namun pijakan dalam berpikir mereka berbeda dengan Ibnu Khaldun, mereka lebih menekankan dan didominasi oleh pijakan akal dan rasional 


\section{Daftar Pustaka}

A. Mukti Ali, Ibnu Khaldun dan Asal-Usul Sosiologi, Yogyakarta: Yayasan Nida, 1970

Abdul Munir Mulkhan, Paradigma Intelektual Muslim Pengantar Filsafat Pendidikan Islam dan Dakwah, Yogyakarta: Sipress, 1993

Abdurrahman an-Nahlawi, Prinsip-prinsip dan Metode Pendidikan Islam dalam Keluarga, di Sekolah dan di Masyarakat, Bandung, Diponegoro, 1992

Abdullah Nasih Ulwan. Pendidikan Anak menurut Islam kaidah-kaidah, Remaja Rosdakarya, Bandung, 1992.

Abdurrahman an-Nahlawi, Prinsip-prinsip dan Metode Pendidikan Islam dalam Keluarga, di Sekolah dan di Masyarakat, Bandung, Diponegoro, 1992.

Ahmad Syafi'i Ma'arif, Ibnu Khaldun dalam Pandangan Penulis Barat dan Timur, Jakarta : Gema Insani Press, 1996

Ali Abd al-Wahid Wafi, Ibnu Khaldun Riwayat dan Karyanya, Jakarta: Grafiti Press, 1985

Ali Abd al-Wahid Wafi, Ibnu Khaldun Riwayat dan Karyanya, Jakarta: Grafiti Press, 1985

Ali al-Jumbulati, Perbandingan pendidikan Islam, terj. H.M. Arifin, Jakarta: Rineka Cipta, 1994

Athiyah al-Abrasyi, Ruh at-Tarbiyah wa Ta'lim, Dar-al-Ihya': Bab al-Halabi, tt , al-Tarbiyah al-Islamiyah wa Falasifatuha , Dar al-Fikr, tt

Ali Ashraf, Horison Baru Pendidikan Islam, terj. Sori Siregar, Jakarta: Pustaka Firdaus, 1993.

Ali Fikri, Tarbiyatul Banin, Beirut: Libanon, Dar al-Kutub Ilmiah, tt.

Ahmad Syafi'i Ma'arif, Ibnu Khaldun dalam Pandangan penulis Barat dan Timur, Jakarta: Gema Insani Press, 1996.

Ahmad D. Marimba, Pengantar Filsafat Pendidikan Islam, Bandung: alMa'arif, 1989.

Agus Soejono, Aliran Baru Dalam Pendidikan, Bandung: CV. Ilmu, 1978.

Asma Hasan Fahmi, Sejarah dan Filsafat Pendidikan Islam, terj. Ibrahim Husein, Jakarta: Bulan Bintang, 1979.

B. Lewis, et. Al., The Encyclopedia of Islam, Tuta Subagide Pallos EJB, London : Inzac, 1971 
Cik Hasan Bisri, Penuntun Penyusunan Rencana Penelitian dan Penulisan Skripsi: Bidang Ilmu Agama Islam. Ciputat: Logos Wacana Ilmu,1998. Cik Hasan Bisri dan Eva Rufaidah, Model Penelitian Agama dan Dinamika Sosial, Jakarta: Raja Grafindo Persada, 2002,

Dja'far Siddik, Analytica Islamica, Vol.7 No.2, 2005.

John Dewey, Democracy and Educatioan New York: Tehe Macmillan Company, 1980.

Kartini Kartono, Psikologi Anak (Psikologi Perkembangan), Bandung, Mandar Maju, Cet. I, 1995.

Fathiyah Hasan Sulaiman, Ibnu Khaldun Tentang Pendidikan, terj. Azra'i Zakariya, Jakarta: Minaret, 1991.

Mesir: Maktab Nahdah, 1964.

http/www. Ummu syauqi hafiduzl, pendidikan usia dini di awal sekolah dasar. com

http:/kangjumari.blogspot.com/2007/12/ontology-pendidikan-islam. Html. Ibnu Khaldun, Muqaddimah Ibnu Khaldun, Mesir, Dar al-Fikr: tt Imam barnadib dan Sutari Imam Barnadib, Beberapa Aspek Substansial Ilmu Pendidikan, Yogyakarta: Andi Offset, 1996.

Lexy J. Moleong, Metodologi Penelitian Kualitatif Bandung : Remaja Rosda Karya, 1993.

Muhammad Qutb , Minhaj al-Tarbiyah al-Islamiyyah, Beirut: Dar- al-Syuruq, Cet. VII, 1983.

Muslim, Shahih Muslim Juz II, Dar al-Fikr, tt.

Morris L. Bigge, Leraning Theories For Teacher, New York: Harper dan Row Publishers Inc., 1994.

Muhibbin Syah, Psikologi Belajar, Jakarta: Logos, 2001.

M.A. Enam , Ibn Khaldun His Life and Work, New Delhi: New Taj Offser Press, 1979

M. Lenoil, Educational Ideologies Comtemporary of Educational Philosophies, Yogyakarta, Pustaka Pelajar, alih bahasa: Intan Naumi, 2001.

M. Arifin, Hubungan Timbal Balik Pendidikan Agama di Lingkungan Sekolah dan Keluarga, Jakarta, Bulan Bintang, 1979.

Nashruddin Thoha, Tokoh-tokoh Pendidikan Islan dizaman Jaya Iman Ghazali dan Ibnu Khaldun, Jakarta: Mutiara,

Noeng Muhadjir, Metodologi Penelitian Kualitatif, Yogyakarta: Rake Sarasin, 1989. 
Omar Muhammad al-Toumy al-Syaibani, Falsafah Pendidikan Islam, terj. Hasan Langgulung, Jakarta: Bulan Bintang, 1979.

Osman Raliby, Ibnu Khaldun Tentang Masyarakat dan Negara, Jakarta: Bulan Bintang.

Omar Moh. At-Thoumi, Falsafah Pendidikan Islam, terj. Hasan Langgulung, Jakarta: Bulan Bintang, 1992.

Sutrisno Hadi, Metodologi Research, Yogyakarta: 1993.

Sutan Zanti Arbi, Pengantar Kepada Filsafat Pendidikan, Jakarta: Depdikbud. Dikti p2LPTK, 1988.

Samuel Smith, Gagasan-gagasan Besar Tokoh dalam Bidang Pendidikan, Jakarta: Bumi Aksara, 1986.

Syaiful Bahri Dmjamarah dan Aswan Zain, Strategi Belajar Mengajar, Jakarta: Rineka Cipta, 2002.

S. Nasution, Didaktik Asas-Asas Mengajar, Bandung: Jemmars, 1986.

Soejoed, Aliran-aliran Pendidikan dan Pengajaran dengan Tokoh-tokohnya, Yogyakarta: IKIP, 1977.

Sukamta, Ingatan dan Lupa, Obyek dan Fungsi Perasaan (Suatu Pengembangan Program Studi), Yogyakarta: Fak. Tarbiyah IAIN Sunan Kalijaga, 1990.

Winarno Surachmad, Dasar dan Teknik Reseacrh, Bandung : Tarsito, 1972

W.J.S. Poerwadarminta, Kamus Umum Bahasa Indonesia, Jakarta, Balai Pustaka, 1999.

Y.B. Suparlan, Aliran-aliran Baru dalam Pendidikan, Yogyakarta : Andi Offset, 1984.

Zaenal Abidin Ahmad, Ilmu Politik Sejarah Islam dan Umatnya Sampai Sekarang (perkembangan dari Zaman ke Zaman, Jakarta: Bulan Bintang, 1979 